DOI: https://doi.org/10.31874/2309-1606-2019-25-2-2

удК: 37/022

\title{
Сергій Пролеєв
}

\section{Шанси освіти у глобальному світі}

\section{Анотація}

у статті розглядається виклик освітній системі, який постає з соціокультурного контексту та умов глобального світу. Робиться наголос на культурно-історичному характері виникнення та розвитку інституту освіти.

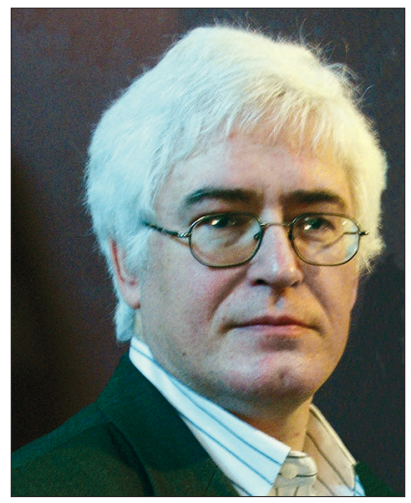
Специфіка його нинішнього стану пов'язується з переходом від стану «всезагальної освіченості», властивого добі модерну, до локалізації освіченості в спеціалізованих групах та середовищах як характерного тренду глобальної дійсності (феномен «освітнього архіпелагу»). В цих умовах шкільна освіта отримує особливе призначення. Вона стає засновком здатності особи до самовизначення в мінливому і позбавленому об'єктивної єдності світі. Відповідно на перший план висувається обдарованість як потенціал розвитку особи. Аналізуються хиби розхожого розуміння обдарованості, виявляється ї̈ зв'язок з сутністю людини. Розкривається сенс обдарованості як негативної та позитивної освітніх задач. Ключовим результатом розвитку обдарованості в школі складає відкриття учнем свого покликання. У вигляді покликання особа відкриває смислову перспективу свого життя та визначає сценарій життєдіяльності в дорослому стані.

Ключові слова: Глобалізація, криза освіти, школа, обдарованість, покликання особи.

Освіта узвичаєно сприймається як одна з невіддільних складових культури та людського буття взагалі. Видається, що вона існувала споконвіку, незаперечно існує нині та буде існувати завжди. Змінюються їі форми, зміст, інституції, спрямування, система цінностей, ролі учасників тощо. Але сам феномен та соціальний інститут освіти залишається неусувним у своєму фундаментальному соціокультурному та інтелектуальному покликанні. Такий статус освіти виглядає самоочевидним. Підставою для нього $є$ хоча б те напозір неспростовне твердження, що людський світ не може існувати (і тим більш розвиватися) без трансляції досвіду поколінь, без постійного опанування новими генераціями здобутих людством знань, культурних практик, зрештою - патернів соціального життя. Відомий вираз «культура починається з освіти» є свідченням такого сенсу освітніх зусиль. Як зазначав Д. Д’юї, «за допомогою розмаїтих виховних засобів суспільство свідомо чи несвідомо перетворює, здавалось 
би, «чужих» і «невтаємничених» у захисників своїх інтересів та ідеалів... Проблема навчального процесу полягає у передаванні досвіду згідно з інтересами, метою та ідеалами суспільства» (Д’юї, 2003: 15).

Однак в яку ситуацію потрапляє освіта нині - в умовах глобального світу? Наскільки істотно трансформуються її функції й саме покликання в надпотужному інформаційному середовищі сьогодення, яке стало визначальним чинником сучасної цивілізації? В чому полягають корені нинішньої кризи освіти і які можливості її подолання? Це коло питань буде визначальним для подальших міркувань.

Для їх осягнення звернемося попервах до генеалогії освіти як окремого інституту культури. Далі позначимо умови, за яких освіта досягає всеосяжного характеру в суспільстві (явище всезагальної освіченості). Наступний крок - простежити характер змін в ролі освіти в глобальному світі. I нарешті спробуємо окреслити деякі концептуальні засади освітніх практик, що здатні відновити значущість освіти в життєдіяльності сучасної людини.

\section{Скільки існує освіта?}

Що здається самоочевидним далеко не завжди є достовірним. Подібне спостерігаємо й у випадку освіти. Насправді освіта порівняно молоде історичне явище. Звісно, скільки існує людина, стільки ж триває процес передачі культурного досвіду та витворених людиною форм життя. Однак ототожнювати з освітою цей процес $є$ не зовсім коректним. Починаючи від опанування новонародженою людиною мови й навичок комунікації та спільного (зрештою суспільного) життя до розвинених спеціалізованих культурних практик (як от полювання, землеробство, будівництво тощо) процес їх освоєння відбувається безпосередньо в ході самої життєдіяльності особи. Так, здійснюється соціалізація, набувається культурний досвід, особа стає повноцінним учасником суспільства і його продовжувачем, і все це типологічно подібне до того, що досягається в процесі освіти. Однак відсутня ключова ознака освіти як такої - її інституційна автономія в загальному масиві культурного життя.

Освіта у власному сенсі слова з'являється там і тоді, де і коли виникає особливий культурний топос - особливим чином організоване місце (частина соціокультурного простору), головним призначенням якого $\epsilon$ оволодіння культурним досвідом, поєднане з самовизначенням особи та опануванням певної перспективи розвитку. Останні два аспекти треба наголосити.

Традиційні, інтегровані в безпосередній процес життєдіяльності форми відтворення культурного досвіду та усталених патернів життя $€$ не стільки освітою, скільки виучкою-для-справи. Часто вони працюють 
просто в режимі культурної пам'яті та відтворення традиції. Роль особистого вибору в них мінімізована, тоді як задача інтеграції в соціальну та культурну систему окремої особи є домінуючою. Між тим освіта - особливо в її вищих, спеціалізованих формах - передбачає залучення в неї на основі особистого самовизначення, здійснюваного особистістю світоглядного, екзистенційного та інтелектуального вибору.

Не випадково виникнення інституту освіти цілком доречно пов'язують з діяльністю Сократа та софістів на грунті полісного життя. Відомий софістико-сократичний поворот в античній філософії не в останню чергу втілився саме в цій фундаментальній культурній новації. Софістичні навчальні гуртки (і серед них історично найвідоміший - сократівський) стали першими власне освітніми інституціями. Способом їх утворення та інтеграції був вільний вибір учасників на користь певних інтелектуальних вправ. Сам формат їх існування стверджував особисту автономію (і то не лише суто інтелектуального, а й цілком соціального гатунку).

Показово, що саме з подібних навчальних осередків вже за часів пізнього середньовіччя з'являться перші європейські університети. Сучасний дослідник середньовічної культури Г. Кенігсбергер так описує цей процес: «Початково учні збиралися навколо одного або декількох відомих вчителів, з плином часу з таких спілок «учнів» і «магістрів» формувалися постійні установи, які пропонували систематичну освіту за цілою низкою предметів (Кенігсбергер, 2001: 207). Часова та історична відстань між софістичними гуртками і цими ембріонами університетів величезна - понад півтори тисячі років, але типологічна подоба вкрай показова.

3 цим другим аспектом освітньої практики - режимом особистого самовизначення - тісно пов'язаний і третій: опанування перспективи розвитку. Зазвичай (особливо коли йдеться про школу) наголошують на репродуктивній функції освіти: статично осягнута соціалізація, «засвоєння (наявних) знань та навичок» тощо. Загалом за сукупністю освітніх зусиль в цій оптиці стоїть відтворення соціальної системи та усталених ціннісно-світоглядних диспозицій. Звісно, передбачається «розвиток» у вигляді росту та примноження заданої соціокультурної потуги, але без суттєвої зміни властивих їй засад.

Подібний погляд на освіту $є$ щонайменше однобічним. Він дійсно констатує одну з наріжних функцій освіти - освоєння культурного досвіду та відтворення наявної системи життєдіяльності. Але сама ця функція радше успадкована освітою від попередніх історичних форм культурної пам'яті та відтворення традиції, ніж $є$ власним осердям освіти як такої. I якраз в тій точці культурного розвитку, коли освіта досягає всезагальної значущості, це оприявниться найвиразнішим чином. 
Освіта покликана забезпечити не тільки відтворення існуючого світу, а й відкривати перспективу його розвитку, створювати засади для розгортання нового смислового горизонту та креативного творення майбутнього. Цю амбівалентність освіти аналізує В. Шамрай, яка слушно зазначає: «У соціокультурному покликанні освіти присутня неусувна двоїстість, амбівалентність. 3 одного боку, освітня система призначена для відтворення суспільства, трансляції його культурного досвіду та знань, тяглості існуючих соціальних диспозицій, морально-правової нормативності, світоглядних та життєвих цінностей тощо. Фактично освіта виступає гарантом спадковості та перманентності існування суспільства. 3 іншого боку, саме освіта $є$ основним ресурсом, який забезпечує потенціал інновацій та розвитку. Тобто підтримує режим перегляду та скасування, перетворення наявних життєвих та соціальних форм» (Шамрай, 2016: 75). Безумовно, з поняттям нового щодо більшості історичних культур та суспільств треба поводитися обережно. Інноваційність, як правило, не була їх метою, а часто навіть сприймалася негативно - як загроза, а не бажаний здобуток. Разом з тим, в той чи інший спосіб освіта передбачає не тільки наявну реальність, а й створення можливостей і спонук виходу за їі межі (щонайменше у вигляді примноження iㅣ потуги, вищих досягнень за існуючими зразками тощо).

\section{Час всезагальної освіченості}

Вочевидь освітні системи та практики глибоко відмінні в різних цивілізаціях. Відповідно зазначені три виміри освіти так само мають несхожий вигляд та механізм дії. Антична освітня модель від початку робить наголос на самодіяльності особи - «як особистості прожити краще життя?» Натомість, китайська модель з характерним приматом державної регламентації на справжній фетиш перетворює систему екзаменів - зрештою, суворих взаємопов'язаних правил та приписів. Однак цей контраст не має вводити в оману: і традиційна китайська освіченість надає доброчесності та естетичним навичкам (тій самій поезії чи каліграфії) не меншої ваги, ніж знанню законів; в інший спосіб, застосовуючи інакшу систему спонук та мотивацій, китайська освіта також забезпечує (та передбачає) не лише відтворення сталого порядку, а й соціальну динаміку та особисте самовизначення.

Також для цих історичних світів, розташованих на протилежних краях євразійського континенту, властива своєрідна елітарність освіти. Твердження може здатися на перший погляд дивним й навіть обурливим - зважаючи, зокрема, на те, що освіченість складає невіддільну ознаку громадянина, тобто людини в стані рівності прав та свободи. Однак треба зважити на замкнений характер античного громадянського 
суспільства. Громадянська спільнота полісу далеко не охоплювала всієї маси населення країни (досить згадати про відсутність активного громадянства у жінок). Відтак освіченість, що супроводжувала феномен громадянства, водночас виступала як своєрідний становий привілей, ознака вільної повноправної особи. До цього слід додати особливий наголос, який робився на давньогрецькій пайдеї («освіченості») як критерію розрізнення елліна та варвара. Освіта виступала вагомим (хоча далеко не єдиним) маркером соціальної й загалом людської вищості особи серед всієї сукупності їй подібних.

В досить специфічний спосіб, але вже в цю епоху освіта окрім своєї конкретної ролі в життєдіяльності набуває характерного значення ціннісного осердя людського як такого. Просто кажучи, освічений $€$ більшою мірою людиною, ніж освіти позбавлений. Так $є$ тому, що освіта окрім конкретних якостей та переваг наближає особу до свободи, виводить її визначеність за межі безпосередньої функціональності та логіки суто життєвих повсякденних потреб. Цей високий ціннісний статус освіти підсилюється як в західній, так і китайській традиції стійким визнанням ролі та ефекту раціональності (сказане не означає, що лише в цих цивілізаціях раціональність мала пріоритет; протилежність культурних прикладів використана лише для того, щоб підкреслити суголосність деяких визначальних рис освіти навіть в радикально відмінних культурних світах). Автономія розуму, яка стала принципом існування ще античної цивілізації (і уособленням чого стала філософія), відтоді ніколи не зникала і давалася взнаки в західній культурній традиції.

Разом з тим навіть в європейській історії освіта - підкреслимо це ще раз - протягом століть й навіть тисячоліть розвитку цивілізації залишається істотно становою ознакою. А відтак - зберігає соціально локальний характер. Уявити геть усе населення освіченим за античної чи середньовічної доби є нонсенсом. Понад те: за усієї значущості, освіта здебільшого не відіграє роль чільної, вищої соціальної ознаки. Показовою в цьому плані $є$ розповсюдженість грамотності, яка виступає однією з базових характеристик освіченості. Невміння писати не завадило Карлу Великому створити Західну імперію і покласти початок новому етапу історії європейської цивілізації; так само неграмотність європейських феодалів не перешкоджала їх ролі пануючої верстви суспільства.

Ситуація змінюється лише з початком модерної доби. Християнська реформація та переклад Святого Письма національними мовами поставили у принципово інший контекст питання грамотності (нагадаємо, що згідно були папи Григорія IX від 1231 року читання Біблії навіть латиною було прямо заборонено мирянам і вважалося церковним злочином протягом тривалого періоду - заборона формально скасована лише y XX столітті; хоча того ж року папа надає права самоврядування Па- 
ризькому університету, що показує неоднозначне ставлення церкви до освіченості (Лінч, 1994: 329)). Лише просвітництво, рішуче відкинувши владу традиції і надавши самочинному розуму (об'єктивній істині) роль вищої інстанції в усіх справах, тим самим проклало шлях до всезагальної освіченості. Освіта стала покажчиком людської якості й навіть людської гідності. Невігластво виводило тебе за межі людства, виглядало ураженням людяності як такої. Не випадково модерний університет, який не лише був головною освітньою інституцією, а й водночас відігравав роль провідної наукової установи, виглядав квінтесенцією культури, її своєрідним храмом.

Всезагальна освіченість, обгрунтована просвітництвом як принцип та фундаментальна соціокультурна вимога, історично реалізувалася протягом досить тривалого, складного і драматичного процесу. Так, лише в середині XIX століття англійські університети (Королівський коледж у Лондоні та Бедфордський коледж) дозволяють навчання жінкам, відкриваючи для них шлях здобуття вищої освіти. І це йдеться про Англію - незаперечного економічного, політичного та інтелектуального лідера тодішнього світу! Однак попри всі перепони, всезагальна освіченість стрімко стає культурним та соціальним пріоритетом. Наступне, XX століття, можна назвати часом розквіту всезагальної освіченості. Одночасно це період вищого авторитету науки (забезпеченого, зокрема, її тріумфальними відкриттями та винаходами другої половини XIX - початку XX століття) й так само вищого піднесення індустріальної цивілізації. Збіг цих трьох виданих історичних явищ - всезагальної освіченості, тріумфу науки та апофеозу індустріального суспільства - не $є$ випадковим. Це процеси, що обумовлювали й живили один одного.

\section{Соціальна топографія освіти: утворення «архіпелагу»}

Наприкінці XX століття динаміка розвитку цивілізації відчутно змінюється. Науково-технічний прогрес від середини XX століття, стрижнем якого стала інформаційна революція, глибоко трансформував структуру людської життєдіяльності. Промисловість й навіть загалом виробництво обіймають все скромніше місце в структурі навіть економіки, не кажучи про соціум в цілому.

Людина освічена перестала бути всезагальним запитом. На перший план вийшов користувач інформаційно-комунікативних технологій. Зважаючи на те, що дані технології здебільшого існують у вигляді готових пристроїв (гаджетів) та впорядкованих інформаційно-комунікативних систем (на кшталт соціальних мереж), вправність такого користувача набуває цілковито інструментального характеру. Якщо навіть вийти за межі власне інструментів, то вся креативність цього героя 
нової епохи виявиться лише кмітливістю операцій з різноманітними культурними кодами. Ця глибоко технологізована в своїй основі справа потребує неабиякої виучки, але мінімізує власне освітній запит. Освіта, як не парадоксально, в інформаційному світі стає все менш потрібною. Світ, в якому діяльність все повніше перероджується на суто дискурсивно-комунікативний процес, маргіналізує освіту разом з наукою та виробництвом. Не наука, а риторика - ось хто на сьогодні став поки що завуальованим, але реальним володарем глобалізованої дійсності.

Успіх в глобальній соціальності забезпечує не систематична праця розуму, глибина знань, потуга інтелектуального пошуку, а вправність мовця та, зрештою, соціального актора. Життя все більшою мірою театралізується і запорукою досягнень у ньому стала динамічність комунікативних реакцій, здатність швидкої адаптації до актуальних ситуацій взаємодії та інші складові ролі в «людському, занадто людському» світі. Зважаючи на це, освіта виглядає надто «обтяжливою», громіздкою, мало пристосованою до логіки мінливих і строкатих ситуацій ad hoc. Пріоритетом, як і в «доосвітні» часи стає розвиток корисних навичок, та ж таки виучка. Тому, до речі, спостерігаємо все більшу потугу різноманітних тренінгів, які все відчутніше й успішніше конкурують з освітніми інституціями.

В прагненні відповісти на цей «виклик часу» освітня система намагається стати все більш «практичною», утилітарно корисною. Вона намагається якнайкраще відповідати (а часто й просто потурати) «зацікавленості» споживача освітніх послуг, мало задумуючись над природою його запиту і зазвичай сліпо поспішаючи за ним. Те, що подібна стратегія прирікає освітні інституції на поразку і не здатна забезпечити їх конкурентоспроможність в більш-менш тривалій перспективі, випливає хоча б з досвіду успішних бізнесів. Лише в початковій романтичній ідилії ринку виглядало так, що $є$ незаперечний господар економічної ситуації - споживач, потреби якого визначають запит до промисловості (підприємця), яка цей запит задовольняє. Все більш потужна індустрія реклами (роль якої нині відіграють не лише телеролики, а й солідні наукові фоліанти, виступи поважних суспільних авторитетів тощо), помножена на ефекти інформаційних технологій в суспільстві мас (власне, технологій масових навіювань та формування структур масової свідомості), наочно довели: головний продукт, який має виробити бізнес для своєї тривалої і справді масштабної успішності - це зручний для нього і максимально активний споживач. Сама річ або послуга - предмет споживання - у своєму конкретному змісті та якостях виступає елементом підпорядкованим, інколи просто другорядним.

За такою логікою набули небаченої потуги цілі сектори сучасної економіки (як от фармацевтика, наприклад). Ця ж логіка переважає в усіх 
інноваційних напрямах сучасного бізнесу (зокрема, в продуктах інформаційних технологій). Споживач давно втратив автономію судження (в багатьох вимірах може йтися навіть про втрату здорового глузду, і то не випадковий, а цілеспрямовано створюваний результат), ставши заручником бізнесу. Тому стратегія освітніх інституцій, побудована на сліпому догоджанню «запиту» споживача відповідних послуг, є архаїчною та програшною. Успіху здатен досягти лише той підприємець (і освітній підприємець не є винятком), який сам формує ситуацію споживання свого продукту, а не лише виробляє продукт під спонтанно виниклий запит. Цю нехитру істину ще доведеться відкрити найбільш успішним освітнім інституціям, які виживуть в жорсткій конкурентній боротьбі сучасності, і успішність їх буде прямо залежна від здатності діяти саме за сценарієм формування свого споживача та відповідної потреби. Закон успішного бізнесу: виготовляйте насамперед потребу - виготовлення продукції (послуги чи речі) прийде навздогін. I той продукт $є$ насправді інноваційним (і найкращим у цій якості), який інспірує потребу та запит, яких до того часу не існувало на ринку.

Разом $з$ тим, до яких би стратегій діяльності не вдавалися сучасні освітні установи, треба цілком ясно зрозуміти: епоха всезагальної освіченості скінчилася. У глобальному світі (як це не парадоксально на перший погляд) освіта повертається до позиції локальних місць, до ролі фрагментів соціального простору. Тепер, як і за доби середньовіччя, та й переважної частини історії, вона спрямована на окремі групи, а не всю людність. Нові й нові намагання будувати освітні моделі за логікою всезагальної освіченості будуть зазнавати все відчутніших невдач. Образно кажучи, в плані соціальної топографії освіта з неозорого суходолу перетворюється на архіпелаг різноманітних островів.

\section{Пригадати обдарованість}

Якщо змальована вище картина відповідає дійсності, вочевиднюється висновок, що на сьогодні освіта - в умовах глобального світу - переживає глибоку метаморфозу. Своєю чергою це спонукає продумати наново засновки освітньої діяльності, iї сенс та ії телеологію. Сказане не означає, буцімто до сьогодні сенс освіти залишається не з'ясованим, а наголошує на іншому загальновизнаному принципі: якщо істотно змінюється дійсність, то не менш істотно змінюються всі їі складові - всі вагомі соціальні інституції, які в ній працюють та ії̈ зрештою утворюють і структурують. Саме ця обставина вимагає в нових умовах переосмислювати сенс деяких начебто давно відомих речей. I така важлива для життєдіяльності людини система як освіта жодним чином не може бути винятком. Як справедливо визначала Х. Арендт: «Криза знову по- 
вертає нас назад до запитань як таких і вимагає від нас або нових, або вже відомих відповідей, але в кожному разі прямих суджень. Криза стає катастрофою тільки тоді, коли ми підходимо до неї з уже готовим заздалегідь судженням, тобто з упередженням. Такий підхід не тільки загострює кризу, а й позбавляє нас відчуття реальності та можливості для роздумів над тим, що саме відбувається» (Арендт, 2002: 182).

Принагідно наші міркування обмежимо ситуацією шкільної освіти, оскільки інші її рівні та формати потребують інакшої логіки розгляду.

Вихідне наріжне питання в контексті переосмислення шкільної освіти має наступний вигляд: на що мають бути спрямовані освітні зусилля у школі, яка існує в умовах нинішнього глобального світу та надпотужного інформаційного середовища?

На перший погляд видається, що школа зберігає свій традиційний засновок: вона інтегрує покоління «новоприбулих» в цей світ осіб в існуючий культурний, інтелектуальний та соціальний простір. Слідом за цим орієнтиром постають знайомі поняття «оволодіння знаннями» («началами наук»), «соціалізація», «розвиток навичок» тощо. Звісно, годі заперечувати репродуктивну та соціально-інтегруючу роль шкільної освіти. Але навіть цю свою традиційну роль школа не здатна успішно виконати в нових умовах мінливого, інакшого за природою світу, застосовуючи усталений і давно випробуваний арсенал освітніх засобів. Чому? Тому що донедавна світ являв собою усталену структуру, був досить стабільним смисловим порядком. Для всієї індустріальної епохи він мав далеко не в усьому звідану, але об'єктивно дану і повсякчас відтворювану основу у вигляді природи, в опануванні та перетворені якої людство вибудовувало свій власний світ.

На сьогодні дійсність втратила цей наріжний камінь своєї певності. У всеосяжному глобальному світі людина має справу в першу чергу не з об'єктивністю природи (у вигляді виробництва), а з суб'єктивністю свого соціального та культурного візаві. Відповідно центр тяжіння життєдіяльності кожного зміщується на те, що кожен несе в собі як свою динамічну здатність, свою спроможність самовиявлення в різноманітних культурних (фахових, комунікативних, соціальних, інтелектуальних тощо) змаганнях, що їх пропонує сучасність - природа та структура наявної ситуації, в якій опиняється індивід. Що це тягне за собою в плані орієнтирів шкільної освіти?

На перший план виходить особистісний та інтелектуальний потенціал учня, його спроможність до життя та продуктивної реакції й інтеракції в неочікуваному і за великим рахунком ще не існуючому світі (зважаючи на солідний часовий лаг між початком і завершенням шкільної освіти, а також враховуючи, наскільки глибоко зміниться дійсність за цей час). Світ, в якому учень починав вчитися, вже в переважній своїй 
частині зникне за період його навчання - і цей новопосталий світ висуне, своєю чергою, нові, інакші вимоги до людини та способів життєдіяльності. За логікою відтворення, це вимагало б знов повертатися на шкільну лаву та знов вчитися, щоб зрештою знов програти мінливому світі: весь час наздоганяти, і ніколи не здогнати.

3 даної картини випливає, що пріоритетом школи має бути не репродуктивна функція опанування наявної дійсності в будь-яких її форматах: знання, навички, вміння, соціальні форми, а передусім примноження потенціалу розвитку особи - інакше кажучи, їі обдарованості. Звісно, і репродуктивна школа певним чином впливала на обдарованість та створювала можливості її розвитку. Так само й сучасна школа не позбавляється традиційної репродуктивної функції: значна частка зусиль та енергії людської життєдіяльності з необхідністю має припадати на відтворення сталої дійсності - це те, що забезпечує вимір стабільності та спадковості світу. Йдеться не про заміну однієї функції іншою, а про зміну пріоритетів та новий баланс між різними функціями та вимірами освіти.

Цю доволі очевидну річ доводиться спеціально зауважувати, зважаючи на в'їдливі звички вітчизняного освітянсько-начальницького хисту: як тільки з'являється якась інноваційна пропозиція, геть весь освітній формат переписується під неї, наче все інше перестає існувати. Внаслідок цього рух освітянського корабля нагадує низку зиґзаґів: всі гуртом рвонули в один бік, потім так само всі гуртом в інший. Вочевидь, від таких імпульсивних і нестямних змін курсу важко очікувати впевненого просування вперед до мети.

Сила принципу обдарованості як засновку та визначника освітніх зусиль полягає не в тому, що він є щось нововідкрите в педагогічній практиці та організації школи. Імпліцитно освітня система завжди передбачала обдарованість учня як те, з чим постійно має справу вчитель та весь процес навчання. Інша справа, в який освітній контекст була поставлена обдарованість, яке місце як усвідомлений освітній орієнтир вона займала, чим направду вона була в тій чи тій шкільній системі. Тут знову треба звернутися до традиційно властивого школі примату соціальної та інтелектуальної репродуктивності.

\section{Українські шкільні колізії}

Український «Закон про освіту» урочисто оголошує: «Метою освіти $€$ всебічний розвиток людини як особистості та найвищої цінності суспільства, її талантів, інтелектуальних, творчих і фізичних здібностей, формування цінностей і необхідних для успішної самореалізації компетентностей, виховання відповідальних громадян, які здатні до свідомого суспільного вибору та спрямування своєї діяльності на користь ін- 
шим людям і суспільству...» (Закон України про освіту, 2019: Преамбула). До цього насиченого різнобічного побажання важко щось додати. Окрім того, що в наявних умовах, в тому числі цілеспрямовано створюваних шкільною системою умовах, воно просто нездійсненне.

Насправді школа переважно опікується виробленням певної сукупності соціальних звичок (не завжди їх навіть варто називати навичками), що є способом інтеграції особи до існуючого порядку життя. Оскільки багатьма (в тому числі й з тих, хто навчає) цей порядок сприймається як малопривабливий, виникає напруження, протест, а часто й прямий конфлікт між інститутом школи та учасниками шкільної освіти. Здебільшого протести та конфлікти мають пасивний вигляд відчуження чи витіснений вигляд девіантної поведінки. Треба було б вітати протест й навіть конфлікт, що спрямовані на зміну освітньої системи, усунення її недоліків та поліпшення їі стану. Однак в переважній частині неприйняття існуючої системи набуває значно небезпечнішого вигляду девіацій в тілі самої школи.

Висуну припущення, що й сумнозвісний булінг, який стрімко став чи не найгострішою соціальною хворобою сучасної школи, має ту саму природу. На позір виглядає, що булінг є передусім стосунками між дітьми. Однак не важко помітити, що він $є$ перенесенням в дитяче середовище тих схем поводження з дітьми - індиферентне до їх гідності та прагнень підпорядкування системі влади та приписів - що де-факто практикує школа. Інституція репродуктивної школи переважно формує вірнопідданих соціальної системи, опікується створенням та поширенням корисних системі соціальних автоматизмів, реакцій, комунікативних схем та ціннісних диспозицій.

Це домінування соціальної системи бачимо й в меті закону про освіту. Бо після рясних оголошень про «всебічний розвиток людини як особистості» постає підсумок - для чого все це. Читаємо про це «задля чого» в останньому рядку мети: «...підвищення освітнього рівня громадян задля забезпечення сталого розвитку України та ії європейського вибору» (Закон України про освіту, 2019: Преамбула). Здається, що іншого формулювання й бути не може. Інституція школи служить, зрештою, суспільству, і що можна сказати проти сталого розвитку країни (який передбачає якісний поступ) та європейського вибору (за яким стоять кращі стандарти цивілізованого життя)? Однак, попри таку очевидність, маємо тут стару суперечність системи та життєсвіту (про яку ще на зорі своєї інтелектуальної діяльності чимало писав Ю. Габермас (Habermas, 1985)). Не буду зараз відтворювати відомі міркування фундатора комунікативної філософії щодо «колонізації життєсвіту» з боку системи: маємо істотно іншу дійсність і відчутно інші диспозиції. Але ці диспозиції - властиві глобальному світу та глобальному інформаційному середовищу - ще більше підважують спроможності й дійсність систе- 
ми. Домінуючий на сьогодні мережний принцип організації радикально підриває позиції систем як таких. Як не парадоксально, але вимога часу полягає в досягненні системних ефектів шляхом асистемних (в тому числі мережних) рішень та дій.

Хвороби та неефективність нинішньої - репродуктивної в своїй основі - школи глибинно пов'язані саме з застарілою орієнтацією на відтворення системи та намаганням побудувати всю справу освіти як процес інтеграції юних осіб в існуючий соціальний порядок (чи, що по суті те ж саме, в наявний порядок життєдіяльності). 3 новою гостротою оприявнюється давня освітня колізія, про яку образно писала Х. Арендт: «Самій природі людських стосунків властиво те, що кожне нове покоління зростає в середовищі старого світу, а тому підготовка нового покоління до життя в старому світі може означати лише, що хтось хоче вибити з рук новоприбульців їхній власний шанс у створенні нового» (Арендт, 2002: 185).

Обдарованість як головний предмет освітніх зусиль означає переорієнтацію з інтересів соціальної системи як такої на розвиток та автономію особи. У зв'язку з цим може виникнути небезпідставне побоювання, що цей шлях здатен призвести до руйнації суспільства, хаосу і непевності, втрати основ суспільної консолідації та солідарності тощо. Безумовно, будь-які системні зміни містять певні ризики - їх треба чітко усвідомлювати, розуміти їх природу і виробляти відповідні запобіжники. Однак відмовлятися від інновацій через ризики, що їх природно супроводжують, означає прирікати себе на ще більший ризик майже гарантованого історичного програшу - коли змінюватися все одно доведеться, але не в режимі випередження руйнівних ефектів, а наздоганяючи весь світ і вимушено прилаштовуючись до новацій, оскільки старі форми цілковито втратили дієздатність.

Водночас варто задуматися над природою переорієнтації телеології шкільної освіти: з вимог соціальної системи до інспірацій особистого розвитку (зрештою, автономії особи). Адже саме такою метаморфозою було виникнення античного полісу - древнього громадянського суспільства, яке переписало засновки своєї спільності, поклавши в їх основу принцип особистої самоврядності (річ історично абсолютно нечувану, яка основою спільного життя прийняла свободу, а не покору та підпорядкування вищій волі). За логікою тодішніх соціальних систем (згадаймо стародавні близькосхідні деспотії) таке суспільство взагалі не могло існувати чи, щонайменше, було приречене на уразливість і знищення 3 боку більш згуртованих соціумів. Однак історія довела інше.

Так само початок модерної доби був пов'язаний з радикальним переписуванням підвалин соціальності на основі нового принципу суспільної інтеграції, яким стала асоціація осіб у вигляді модерної (політичної) 
нації. Не примат спільноти, а вільне поєднання осіб власною волею в спільність (як от суспільний договір) виглядало в кращому випадку якоюсь філософською абстракцією, а стало, натомість, чільним політикоправовим принципом утворення національної держави та державного урядування. А ще до того з пекла релігійних воєн постав принцип толерантності - свободи совісті - який вочевидь і цілком кричущим чином суперечив ідейній єдності суспільства (і начебто підривав саму можливість його солідарного, консолідованого існування і цим позбавляв його сили та порядку).

Ці історичні приклади наочно доводять, що успіх суспільств аж ніяк не $є$ прямо пропорційним намаганням підпорядкувати життєдіяльність особи вимогам соціальної системи. Тим більш програшним таке прагнення виглядає в наш час.

\section{Освітні перетворення та ефект обдарованості}

Треба віддати належне керманичам української освіти - вони начебто розуміють неблагополуччя української школи і протягом останніх років намагаються послідовно її реформувати. Не будемо оцінювати все, що робилося на цьому шляху, зосередимо увагу на стратегії. Її загальним виразом на сьогодні $\epsilon$ концепція «нової української школи». Маніфест цієї новації, розміщений на сайті МОН, недвозначно оголошує: «Нова українська школа - це ключова реформа Міністерства освіти і науки. Головна мета - створити школу, в якій буде приємно навчатись і яка даватиме учням не тільки знання, як це відбувається зараз, а й уміння застосовувати їх у повсякденному житті» (Нова українська школа, 2019).

Уникнемо коментарів щодо того, чи $є$ те, що дає школа «зараз» 3наннями. Звернімо увагу на два інші моменти: «приємність навчання» та «застосування знань у повсякденному житті». Природа такої «приємності» залишається незрозумілою не тільки в початковому формулюванні, а й загалом з концепції. Через це може виникати непорозуміння: адже навчання це воленс-ноленс праця, й як будь-яка праця вимагає зусиль, напруження, самодисципліни та інших речей, які зазвичай особисто переживаються не як надто приємні. То що, на цій підставі вони мають піти з нової школи, де залишаться самі лише приємності?

Звісно, не варто присікуватися до слова. В прагненні зробити школу місцем, де хочеться і приємно перебувати, нема нічого поганого. Це треба лише вітати. Дуже давно, далеко не в наш час виник вираз «школа - наш рідний дім» (на сьогодні ці слова можуть, на жаль, здебільшого викликати лише сум). Йдеться про те, що без концептуального визначення «приємності» всі інноваційні начебто прагнення перетворюються на порожні і безсилі благопобажання. 
Найбільша «приємність» особистості полягає в її успішному та продуктивному самоздійсненні, в спроможності вести наповнене та зрештою щасливе життя. Обдарованість і $\epsilon$ корелятом цієї спроможності, ïi інтегрованим виразом. Тому вона є головним, з чим має справу вчитель і загалом освітній процес - тим головним, на що спрямовані всі освітні зусилля у школі.

Ще один пріоритет стратегії «нової української школи»- «застосування знань у житті». Його начебто слід тільки вітати: адже тут заявлена інтенція на поєднання змісту навчання з життєвими практиками. Але що в цьому принципі є вразливим?

По-перше, знання неможливо безпосередньо застосувати в житті, бо вивчається знання наукове, об'єктивне, а життєві ситуації - суб'єктивні. Наукові знання придатні до застосування «у житті» лише у вигляді відповідних життєвих практик - трансформовані в кластери так званого «прикладного знання». Взагалі засвоєння знань не має бути самостійною освітньюю метою школи: мають опановуватися сенси, і відповідно - розвиватися здатність розуміння. В центрі навчального процесу має стояти вправність мислення.

По-друге, смислове осердя цього пріоритету утворює знов-таки знання, а не сам суб'єкт, його здатність відкрити власну перспективу самовизначення та реалізувати їі. Не «застосування знань у житті», а соціальна, інтелектуальна, екзистенційна життєздатність особи - ось що має слугувати орієнтиром для діяльності школи. В цьому плані обдарованість і є основою особистої життєздатності - продуктивного життєвого сценарію та спроможності його реалізувати, набуваючи необхідних для цього якостей та досягаючи сприятливої конфігурації умов. Тут необхідно, щоб уникнути непорозумінь, зробити застереження щодо природи обдарованості. Часто її визначають через здібності (рос. «способности»). Тоді вона розуміється як сукупність певних якостей, властивих особі, які вирізняють її поміж інших (пересічних особистостей).

В цьому баченні є дві ключових похибки. Перша стосується буттєвої модальності властивостей з одного боку, і обдарованості - з іншого. Здібності - це наявні властивості: те, що людина може, що вона виявляє як свої навички та здатності. Властивості - це даність, наявне. Натомість, обдарованість - потенційне, відкрита можливість. Ще Аристотель відкрив цю особливу модальність існуючого - буття-у-можливості, на відміну від буття як того, що безпосередньо є, наявне.

Існує принципова різниця між тим, щоб вміти щось конкретне з одного боку, і бути обдарованим - з іншого. В першому випадку маємо чітку певність результату, який логічно випливає з відповідного вміння. В другому - не маємо певності, ефект обдарованості істотно інший. Вона 
дає надію, породжує очікування. Здатність виявляється в дії, обдарованість - відкриває перспективу.

Отже, сама обдарованість ніколи не є безпосередньо наявною, даною властивістю. Вона завжди існує в режимі можливості - як потенція, а не даність. Тут обдарованість відкриває свою спорідненість 3 творчістю. Чим би конкретно вона не була в тому чи тому випадку (обдарованістю щодо чого), вона посутньо визначена своїм креативним потенціалом. Лише наявність виміру відкритої продуктивності дозволяє казати саме про обдарованість, а не просто про конкретне вміння, навичку чи здатність, якими б корисними чи цінними вони самі по собі не були. Існування як потенції є принциповим моментом обдарованості й для її конкретного носія. Який саме завдяки їі потенційному характеру вперше перестає бути лише «носієм» властивості, а перетворюється на персону, котра має для обдарованості конститутивне значення. Для способу буття обдарованості єдино доступною формою актуальної реальності $є$ акт творчості.

Друга вада ототожнення обдарованості з властивостями особи полягає в тому, що обдарованість - не окрема характеристика (якість) людини поруч з різними іншими. Вона - універсальна, всеохопна характеристика, тісно пов'язана з самою сутністю людини. Чому це так?

Тому що людина за своєю сутністю, на відміну від всіх інших істот, не $\epsilon$ щось дане - що можна визначити через сукупність ознак. Як вовка можна визначити через сукупність ознак: «хижий звір», «пазурі», «сіре хутро», «хвіст» тощо. Людина $\epsilon$ не те, що вона $є$, а чим (ким!) вона сама стає. Людина само-визначається. Відтак людина є незавершена істота (відкрита до світу=можливостей існування). Вона стає тим, ким сама себе зробить.

Це наочно демонструє видатний ренесансний гуманіст Піко делла Мірандола в «Промові про гідність людини» (яку зазвичай називають «маніфестом ренесансного гуманізму»): «Бог, завершивши всі справи, як то свідчать Моїсей та Тімей, замислив, нарешті, створити людину. Але не було нічого ані в першообразах, звідки Творець створив би нове потомство, ані в сховищах, що подарував би у спадок новому синові, ані на лавках небосхилу, де сидів сам споглядач всесвіту. Все вже було завершене, все було розподілене по вищих, середніх і нижчих сферах <...> Отже, Господь згодився, що людина - створіння непевної подоби, і так промовив, поставивши її в центрі світу: «Ні сталої осілості, ні власної подоби, ні певної служби не даємо Ми тобі, о Адаме, і яку осілість, подобу чи службу ти забажаєш, таку за власною волею і з власного розсуду отримаєш і володітимеш нею. Природа решти істот зневолена межами Наших законів - ти ж, жодними путами не зневолений, за своєю волею, в руки якої Ми тебе віддаємо, визначиш собі подобу. Я поставив тебе 
в центрі світу, щоб ізвідти тобі було зручніше оглядати все, що існує в ньому. Ми не зробили тебе ні небесним, ні земним, ні смертним, ні безсмертним, щоб ти сам, ніби вільний і знаменитий скульптор і творець, набув того образу, якому надаси перевагу. Можеш виродитися в нижчі, тваринні істоти, можеш за наміром своєї душі уподібнитися до вищих, божественних» (Піко делла Мірандола, 2013: 54).

Тому розуміти обдарованість як суму здібностей - невірно. Людина не $€$ даністю, вона не сума властивостей, а завжди щось більше. Вона $€$ тим, ким сама стає. Це втричі вірно відносно дитини. Дитина не є. Вона істота, що набуває можливості бути. Можливо, це звучить доволі абстрактно і на позір важко прилаштовується до поточних реалій української школи. Однак йдеться насправді про гранично конкретні речі. Набуття обдарованості виявляється передусім у відкритті особою самої себе: того в собі, що може стати основою її життєвого сценарію, в чому саме має полягати цей сценарій, готовність його здійснювати й змінювати себе відповідно до цієї задачі. Не в абстрактній сукупності «дарів» (здатностей) полягає обдарованість, а в особистій готовності й волі до розвитку, в тверезому осягненні своїх сильних та слабких рис і вмінні використовувати найскромніші власні надбання.

Для ілюстрації наведу приклад сліпого чорношкірого хлопчика 3 бідної родини Америки 1950-х років. Вже в наведених характеристиках криється вирок. Яка могла його очікувати доля? Але одного разу вчителька попросила його - сліпого - допомогти їй спіймати мишу, яка своїм пищанням заважала вести уроки. Хлопчик завдяки тонкому слуху чітко вказав, де саме знаходиться миша. І головне - зробив з цього вирішальний для своєї долі висновок. 3 цього відкриття себе почався уславлений Стіві Вандер, про якого енциклопедія повідомляє: «Американський соул-співак, композитор, піаніст, барабанщик, харпер, музичний продюсер і громадський діяч, що справив величезний вплив на розвиток музики ХХ століття».

Обдарованість $€$ потенціалом людського в людині - це можна вважати її вихідним визначенням. Втім, недостатньо обмежитись самим лише визначенням - хоч стислим, як це було зроблено, хоч будь-яким розлогим. Обдарованість має бути осягнута як освітній принцип - тобто як вкрай важливий чинник освітнього процесу, який певним чином задає структуру, зміст та спрямованість цього процесу.

\section{Розхожі хиби розуміння обдарованості та категорія покликання}

У побудові такої теорії передусім потрібно вирішити негативну теоретичну задачу - подолати розхожі хиби в розумінні обдарованості. Розгляну три найбільш поширені. 
Хиба перша полягає в розумінні обдарованості як суми здібностей, що перевищують середній рівень. Звичайні здібності відтак не розглядається як обдарованість. От вищі за звичайні, щось особливе - то вже обдарованість. Тут починається віковічна суперечка - всі діти обдаровані чи ні?

Мимоволі обдарованість постає як кількісний показник - вище середнього. Натомість, обдарованість - не кількісна, а якісна характеристика. Понад те - не наявна якість, а потенціал, відкрита можливість (про що йшлося вище). Це, зрештою, якість самовизначення особи - як їй вдалося бути собою і здійснити себе в обширі людського як такого. Обдарованість кожного треба осягати у співвіднесені з ним самим: це наповненість того, як і в чому ти сам знайшов себе. Опорою і наріжним каменем обдарованості є здатність бути самим собою. Звісно, мається на увазі не проста тотожність з собою, властива кожному предмету, а вибір та здійснення себе як конкретного життєвого проекту, сенс якого ти визначаєш в даних соціальних реаліях, але в якомога ширшому і насиченому культурному полі. Ти насправді стаєш сам собою в обширі людяності - тих культурних, історичних, екзистенційних можливостей, що їх напрацювало людство протягом своєї історії.

Хиба друга: обдарованість розуміється як певна окреслена характеристика суто особи (їі розуму, волі, характеру, чуттєвості тощо). Хтось має потенціал розвитку, а хтось його позбавлений. Ідея задатків - чи то вроджених, чи то інспірованих вихованням та власною активністю особистості - оприявнює даний погляд найбільш наочно.

Натомість, обдарованість $є$ не суто персональною властивістю, а передусім соціокультурним феноменом. Вона має посутньо не суб'єктну, а інтерсуб'єктивну природу. Якщо, наприклад, йдеться про обдарованість дітей та молоді, то хто є носій обдарованості - дитина чи дитинство, персоналія чи стан, особа чи вік? Талановитим є суспільство, яке сприяє індивідуальному розвиткові, чи окремий індивід? I чим, зрештою, є сама обдарованість - особистою якістю, чи системно організованою культурною програмою, дискурсивною практикою, в яку особи лише залучаються як її живі учасники?

Позитивна відповідь на перше питання спонукає до уваги щодо $а$ - $^{-}$ тропологічних станів з найбільш високим потенціалом обдарованості; й відтак культурна матриця сприйняття та використання обдарованості мала б набути вигляду оптимального використання цих станів. Позитивна відповідь на друге питання вимагає мислити передусім не особу, а суспільство - вбачати в соціальній системі й усій сукупності життєвих форм (у життєсвіті) справжній феномен обдарованості чи його відсутність. Відповідно індивіди з їх конкретними якостями виступають епіфеноменами, похідними від тотальності життєсвіту та соціуму. 
Позитивно розв'язане третє питання вимагає бачити в обдарованості своєрідну культурну машину цілком імперсонального ґатунку. Це певна система дії та комунікації, інтеракції та ціннісних переваг. Визначення того, чим $є$ обдарованість, закодоване в культурних практиках; обдарованість не $\epsilon$ відверненою особистою властивістю, iї схарактеризовує культурна (навіть культурісторична) віднесеність. То може й «останнім словом» обдарованості, ії засновком $€$ не індивід, а складно організована ціннісно-комунікативно-інтерактивна культурна матриця?

Хиба третя: обдарованість мислиться як безумовно позитивна якість, жадане надбання особистості. Не без того, звісно, що обдарованість створює ситуативні складнощі чи випробування для свого носія, але загалом вона $\epsilon$ незаперечно виграшною ознакою. Якщо застосовувати мову Бурдьє, обдарованість $\epsilon$ вагомим соціальним та культурним капіталом, який посилює позиції особи в суспільстві й обіцяє їй загалом більш наповнене життя.

Але якщо обдарованість імпліцитно передбачає креативність, способом її існування у будь-якій усталеній соціальній системі $€$ напруження і конфлікт. Обдарованість зі своїм потенціалом відкритої продуктивності (й відтак невизначеності наперед) містить виклик і загрозу всьому усталеному та наявному. Соціальна система («середовище») опікується не абстрактною задачею «найкращого життя» чи «розвитку всіх сутнісних сил» людини, а всеохопним прагненням самовідтворення. Цій постійній спрямованості соціальної життєдіяльності обдарованість як така (у вигляді чистого потенціалу креативності) не лише не сприяє, а й заважає. Тому в устеленій соціальній системі обдарованість приречена на конфлікт з наявними та узвичаєними засадами існування (знання, оцінок, успішності тощо). Це вимагає мислити обдарованість не у вигляді позитивного надбання, а у вигляді принципового й неуникненного конфлікту, в тому числі внутрішнього конфлікту особистості з самою собою. Обдарованість з необхідністю кидає виклик наявному стану речей (в тому числі твоїй власній даності).

Відтак обдарованість постає феноменом, що з необхідністю виходить за межі соціальності і повинен ствердити себе всупереч її усталеним засновкам.

Зі сказаного випливає висновок, що обдарованість складає не лише позитивну, а й негативну освітню задачу. Обдарованість, з огляду на їі природу потенції, неможливо формувати. Їй можна лише сприяти. Відтак задача формування обдарованості $є$ хибна, безпорадна. Адекватна постановка освітньої задачі - сприяти розвитку обдарованості. В цій справі особлива роль належить освітньому (й загалом соціокультурному) простору, який повинен стати ефективним, плідним місцем сприяння розвитку спроможності дитини, підлітка, юнака до самовизначення. 
Однак окрім цієї позитивної задачі і поруч з нею існує обдарованість як негативна задача. Вона полягає в усунені перешкод для розвитку особи, санації (очищення) простору їі існування від несприятливих, руйнівних для самовизначення особи чинників. На віковічне питання «що є людина?» можна образно відповісти: людина $\epsilon$ те, що вона $є$ мінус перепони її розвиткові. Інколи мінус такий великий, що людина стає від'ємною величиною. Запобігання цьому сумному розвитку подій і $\epsilon$ зміст негативної задачі щодо обдарованості. Вагу її в нинішніх несприятливих умовах людського існування важко перебільшити. Без успіху в розв'язанні негативної задачі, не буде успіху і в позитивній задачі сприяння (розвитку) обдарованості.

Найголовнішим здобутком обдарованості учня (а водночас і головним здобутком шкільної освіти, яка покликана сприяти розвитку обдарованості) є відкриття ним свого покликання. Обдарованість і покликання утворюють своєрідну «вольтову дугу» шкільного освітнього процесу. Не в тих чи тих конкретних знаннях, вміннях, навичках, здобутках резюмується обдарованість. Все це важливі, але допоміжні її ознаки та вияви. Найістотнішим і справді вирішальним є визначеність особи у своєму покликанні, яке по суті $є$ проекцією всього її подальшого життя. Весь процес навчання, опанування знань з різних предметних царин та дисциплін, будь-які практичні вміння й випробування мають постати в цілком іншій телеології, а саме як поле пошуку особою свого покликання. I поле не суто інтелектуального, а й соціального, комунікативного, екзистенційного гатунку. Доводиться констатувати, що нинішня школа загубила визначальну для себе філософсько-освітню категорію, що виправдовує та спрямовує їі існування - категорію покликання. Лише відновлення її у правах та відповідна переорієнтація освітнього процесу дозволить школі подолати кризу, яку повсякчас інспірують виклики глобального світу.

\section{Посилання:}

Арендт Х. (2002) Криза виховання й освіти. В: Арендт Х. Між минулим та майбутнім. К.: Дух і Літера, 2002,181-204.

Д'юї Д. (2003) Демократія і освіта. Львів: Літопис, 2003.

Закон України про освіту (2019) URL: https://zakon.rada.gov.ua/laws/show/2145-19 Кенигсбергер Г. (2001) Средневековая Европа. 400-1500 годы. М.: Весь Мир, 2001. Лінч Д. (1994) Середньовічна церква. К.: Основи, 1994.

Нова українська школа (2019) URL: https://mon.gov.ua/ua/tag/nova-ukrainska-shkola

Піко делла Мірандола Д. (2013) Промова про гідність людини (3 латини переклав Назарій Назаров, редакція Ростислава Паранька) Всесвіт. № 11/12, 44-63.

Шамрай В.В. (2016) Освіта та політика в глобалізованому світі. Філософія освіти. Philosophy of Education. №2(19),75-87. 
Habermas J. (1985) Das Verhältnis zwischen System und Lebenswelt im Spätkapitalismus. In: Habermas J. Theorie der Kommunikativen Handelns. 2. Bde. 3, durchges. Aufl. Frankfurt am Main: Suhrkamp Verlag, 1985. Bd. 2,504-522.

\section{References:}

Arendt H. (2002) The crisis of upbringing and education. In: Arendt H. Between Past and Future. K .: Dukh i Litera, 2002,181-204 [in Ukrainian].

Dewey D. (2003) Democracy and Education. Lviv: Litopys, 2003 [in Ukrainian].

Law of Ukraine on Education (2019) URL: https://zakon.rada.gov.ua/laws/show/214519 [in Ukrainian].

Koenigsberger G. (2001) Medieval Europe. 400-1500 years. M.: Ves’ Mir, 2001 [in Russian].

Lynch D. (1994) The Medieval Church. K.: Osnovy, 1994 [in Ukrainian].

New Ukrainian School (2019) URL: https://mon.gov.ua/en/tag/nova-ukrainska-shkola [in Ukrainian].

Pico della Mirandola D. (2013) Speech on human dignity (Translated from Latin by Nazariy Nazarov, edited by Rostislav Paranko) Vsesvit. № 11/12, 44-63 [in Ukrainian].

Shamray V.V. (2016) Education and politics in a globalized world. Filosofiya osvity. Philosophy of Education. №2 (19), 75-87 [in Ukrainian].

Habermas J. (1985) Das Verhältnis zwischen System und Lebenswelt im Spätkapitalismus. In: Habermas J. Theorie der Kommunikativen Handelns. 2. Bde. 3, durchges. Aufl. Frankfurt am Main: Suhrkamp Verlag, 1985. Bd. 2,504-522.

\section{Сергей Пролеев. Шансы образования в глобальном мире}

В статье рассматривается вызов образовательной системе, который возникает из социокультурного контекста и условий глобального мира. Делается упор на культурно-историческом характере возникновения и развития института образования. Специфика его нынешнего состояния связывается с переходом от состояния «всеобщей образованности», свойственного эпохе модерна, к локализации образованности в специализированных группах и сообществах как характерного тренда глобальной действительности (феномен «образовательного архипелага»). В этих условиях школьное образование получает особое предназначение. Оно становится предпосылкой способности личности к самоопределению в меняющемся мире, лишенном объективного единства. Соответственно на первый план выдвигается одаренность как потенциал развития личности. Анализируются недостатки расхожего понимания одаренности, показывается ее связь с сущностью человека. Раскрывается смысл одаренности как негативной и позитивной образовательных задач. Важнейшим результатом развития одаренности в школе составляет открытие учеником своего призвания. В виде призвание личность открывает смысловую перспективу своей жизни и определяет сценарий жизнедеятельности во взрослом состоянии.

Ключевые слова: глобализация, кризис образования, школа, одаренность, призвание личности. 


\section{Sergii Proleiev. Chances of education in the global world}

The article considers the challenge to the educational system, which arises from the sociocultural context and the conditions of the global world. The emphasis is on the cultural and historical nature of the emergence and development of the institution of education. The specifics of its current state consists in the transition from the state of "universal education" characteristic of the modern time to the localization of education in specialized groups and communities as a characteristic trend of global reality (the phenomenon of "educational archipelago"). In these conditions, school education receives a special purpose. It becomes a prerequisite for an individual's ability to self-determination in a changing world devoid of objective unity. Accordingly, giftedness as a potential for personality development comes to the fore. The shortcomings of the common understanding of giftedness are analyzed, its relationship with the essence of man is shown. The meaning of giftedness as a negative and positive educational task is revealed. The most important result of the development of giftedness in the school is the discovery by the student of his vocation. In the form of a vocation, a person opens the semantic perspective of his life and determines the scenario of life in an adult state.

Keywords: globalization, education crisis, school, giftedness, personal vocation.

Пролеєв Сергій Вікторович, доктор філософських наук, професор, завідувач відділу філософії культури, етики і естетики, Інститут філософії НАН України ім. Г.С. Сковороди, професор Національного університету «Києво-Могилянська академія».

E-mail: uffon@ukr.net; https://orcid.org/0000-0003-1563-712X

Proleiev Sergii Viktorovych, Doctor of Philosophy, Professor, Head of the Department of Philosophy of Culture, Ethics and Aesthetics, Institute of Philosophy of the National Academy of Sciences of Ukraine, professor of the National University "Kyiv-Mohyla Academy".

E-mail: uffon@ukr.net; https://orcid.org/0000-0003-1563-712X 